\title{
Analisis Perbedaan Individual dan Implikasi dalam Proses Pembelajaran
}

\author{
Firmansyah* \\ Universitas Islam Negeri Raden Fatah Palembang \\ Jln. Prof. K.H. Zainal Abidin Fikri KM. 3,5 Palembang Sumatera Selatan Kode Pos 30126 \\ *Correspondence email: firmansyah_uin@ @radenfatah.ac.id
}

\begin{abstract}
Abstrak. Penelitian ini membahas beberapa aspek perbedaan secara umum pada setiap individu yang meliputi antara lain perbedaan pada aspek: biologis, psikologis, intelegensi, jenis kelamin, etnis, dan lain sebagainya, serta implikasinya dalam proses pembelajaran di kelas. Penelitian ini adalah penelitian riset kepustakaan (library research), yang bermaksud untuk mengumpulkan informasi yang berkaitan dengan perbedaan individu dan implikasinya dalam proses pembelajaran di kelas. Pengumpulan data penelitian dilakukan dengan menggunakan teknik dokumentasi. Adapun analisis data menggunakan analisis induktif. Berdasarkan analisis data yang telah dilakukan dapat disimpulakan bahwa karakteristik individual masing-masing terletak pada aspek biologis (fisiologis), serta aspek psikologis. Kedua aspek ini membentuk suatu perilaku tertentu pada manusia yang menjadikannya berbeda dengan manusia yang lainnya. Dalam menyikapi perbedaan-perbedaan ini, dalam proses pembelajaran di kelas, guru hendaknya kreatif mengelola proses pembelajaran di kelas agar tujuan pembelajaran dapat dicapai secara maksimal.
\end{abstract}

Kata kunci: Karaktersitik Individu; Perbedaan Individual; Proses Pembelajaran.

\begin{abstract}
This study discusses several aspects of differences in general for each individual which includes, among others, differences in aspects: biological, psychological, intelligence, gender, ethnicity, and so on, as well as their implications in the learning process in the classroom. This research is library research, which aims to collect information related to individual differences and their implications in the learning process in the classroom. Research data collection was carried out using documentation techniques. The data analysis used inductive analysis. Based on the data analysis that has been done, it can be concluded that the individual characteristics of each lie in the biological (physiological) aspect, as well as the psychological aspect. These two aspects form a certain behavior in humans that makes them different from other humans. In addressing these differences, in the learning process in the classroom, teachers should be creative in managing the learning process in the classroom so that learning objectives can be achieved optimally.
\end{abstract}

Keywords: Individual Characteristics; Individual Differences; Learning Process.

\section{PENDAHULUAN}

Secara filosofis, manusia adalah makhluk yang dapat dipandang dari berbagai sudut pandang. Sejak ratusan tahun sebelum Nabi Isa As, manusia telah menjadi objek filsafat, baik objek formal yang mempersoalkan hakikat manusia, maupun objek materiil manusia sebagai apa adanya manusia dan dengan berbagai kondisinya. Sebagaimana dikenal adanya manusia sebagai makhluk yang berfikir (homo sapiens), makhluk yang berbentuk (homo faber), makhluk yang dapat dibentuk (homo educandum), dan seterusnya, merupakan pandangan-pandangan tentang manusia yang dapat digunakan untuk menetapkan cara pendekatan yang akan dilakukan terhadap manusia tersebut. Berbagai pandangan tentang manusia tersebut membuktikan bahwa manusia adalah makhluk yang kompleks (Sunarto dan Ny. B. Agung Hartono, 2008).

Sifat hakikat manusia sebagaimana disebut di atas, oleh Umar Tirtarahardja dan S. L. La Sulo (2008) diartikan sebagai ciri-ciri karakteristik, yang secara prinsipil (jadi bukan hanya gradual) membedakan manusia dengan hewan. Meskipun antara manusia dengan hewan banyak kemiripan terutama jika dilihat dari segi biologisnya. Dalam hubungannya dengan ungkapan tersebut, dapat dipahami bahwa sifat prinsipil yang dimiliki oleh manusia secara hakikat berbeda dengan hewan, perbedaan secara hakikat itu misalnya dalam hal tingkah laku. Rene Descrates sebagaimana diungkapkan Tafsir, berpendapat, bahwa tingkah laku itu ada dua macam, yaitu tingkah laku mekanis yang ada pada hewan dan tingkah laku rasional yang ada pada manusia. Ciri rasional pada tingkah laku manusia adalah ia bebas memilih, sementara pada hewan, kebebasan itu tidak ada. Karena bebas memilih itulah maka pada manusia ada tingkah laku yang mandiri (Tafsir, 2012).

Hal senada juga disampaikan Sudjana (2011), menurutnya, tidak ada dua orang individu yang sama, baik dari segi psikis maupun dari segi fisik. Termasuk kemampuan siswa sebagai individu, juga berbeda satu sama lain. Menuntut kegiatan atau proses belajar dan hasil belajar yang sama dari setiap siswa pada hakikatnya mengingkari adanya perbedaan individu tersebut. Demikian pula menyesuaikan pengajaran kepada orang yang satu dengan yang lain bukanlah cara yang bijaksana. Lebih lanjut menurut Sudjana, prinsip individual tidak berarti memberi pelayanan secara perorangan, akan tetapi menyesuaikan dengan kemampuan rata-rata siswa, memberikan bantuan dan bimbingan kepada siswa yang memerlukannya, memberi kesempatan kepada setiap siswa untuk maju sesuai dengan kemampuannya, serta memberi kesempatan 
kepada setiap siswa untuk melakukan cara belajar yang sesuai dengan dirinya.

Ahmadi sebagimana dikutip Djamarah (2002), mengakui bahwa anak didik selain ada perbedaannya, juga ada persamaannya. Paling tidak ada beberapa persamaan dan perbedaan yang harus mendapatkan perhatian seperti pada aspek kecerdasan (intelegensi), kecakapan, prestasi, bakat, sikap, kebiasaan, ciri-ciri jasmaniah, minat, cita-cita, kebutuhan, kepribadian, dan pola-pola dan tempo perkembangan, serta latar belakang lingkungan.

Dalam perspektif Sardiman (2012), istilah perbedaan individu diistilahkannya dengan karteristik individu (dalam pendidikan bisa dipakai istilah siswa atau anak didik), yang berarti keseluruhan kelakuan dan kemampuan yang ada pada siswa sebagai hasil dari pembawaan dan lingkungan sosialnya sehingga menentukan pola aktivitas dalam meraih cita-citanya. Dalam pada itu, paling tidak ada tiga hal yang perlu diperhatikan, yaitu:

1. Karakteristik atau keadaan yang berkenaan dengan kemampuan awal atau prerequisite skills, seperti kemampuan intelektual, kemampuan berpikir, mengucapkan hal-hal yang berkaitan dengan aspek psikomotor, dan lain-lain.

2. Karakteristik yang berhubungan latar-belakang dan status sosial (sociokultural).

3. Karakteristik yang berkenaan dengan perbedaanperbedaan kepribadian seperti sikap, perasaan, minat, dan lain-lain.

Menurut Philip R.E. Verson dalam Hamalik (2009), pada hakikatnya perbedaan-perbedaan individual adalah perbedaan-perbedaan dalam kesiapan belajar. Setiap anak yang masuk sekolah, masing-masing memiliki tingkat kecerdasan, perhatian, dan pengetahuan yang berbeda dengan kesiapan belajar yang berbedabeda. Mereka berbeda dalam potensi bahkan dalam karakternya. Masalahnya adalah pendidikan yang bagaimanakah yang patut diberikan kepada mereka agar tercapai perkembangan secara optimal bagi tiap individu sesuai dengan kapasitas dan kecenderungankecenderungan mental mereka.

Secara praktis, menurut Syaiful Bahri Djamarah dan Aswan Zain (2010) dan Khadijah (2006), pendekatan individual mempunyai arti yang sangat penting bagi kepentingan pengajaran. Pengeloaan kelas sangat memerlukan pendekatan individual ini. Pemilihan metode tidak bisa begitu saja mengabaikan kegunaan pendekataan individual, sehingga guru dalam melaksanakan tugasnya selalu saja melakukan pendekatan individual terhadap anak didik di kelas. Bahkan kesulitan belajar pada anak didik pun lebih mudah dipecahkan dengan pendekatan individual.

Sehubungan dengan uraian di atas, berikut ini akan dibahas beberapa aspek perbedaan secara umum pada setiap individu yang meliputi antara lain perbedaan pada aspek: biologis, psikologis, intelegensi, jenis kelamin, etnis, dan lain sebagainya, serta implikasinya dalam proses pembelajaran di kelas.

\section{METODE}

Penelitian ini adalah penelitian riset kepustakaan (library research), yang bermaksud untuk mengumpulkan informasi yang berkaitan dengan perbedaan individu dan implikasinya dalam proses pembelajaran di kelas. Sumber primer penelitian berasal dari buku-buku psikologi pendidikan, adapun untuk memperkaya informasi penelitian digunakan sumber data sekunder yang berasal dari berbagai buku dan artikel jurnal yang relevan dengan penelitian ini. Selanjutnya, pengumpulan data penelitian dilakukan dengan menggunakan teknik dokumentasi. Adapun analisis data menggunakan analisis induktif.

\section{HASIL DAN PEMBAHASAN Perbedaan Biologis}

Menurut Djamarah (2010), tidak ada seorang pun yang memiliki kondisi jasmani yang persis sama, bahkan terhadap anak kembar dari satu sel telur pun tetap terdapat perbedaan dalam aspek jasmani. Perbedaan itu seperti pada jenis kelamin, bentuk tubuh, warna rambut, warna kulit, bentuk mata, dan sebagainya. Semua itu adalah ciri-ciri individu anak didik yang dibawa sejak lahir.

Dalam kaitannya dengan faktor-faktor yang mempengaruhi belajar pada aspek biologis (biasa disebut juga dengan istilah fisiologi) yang dimaksud, dalam perspektif Slameto (2010), yaitu: (1) faktor kesehatan. Sehat berarti dalam keadaan segenap badan beserta bagian-bagiannya bebas dari penyakit, dan (2) cacat tubuh. Cacat tubuh yang dimaksud adalah sesuatu yang menyebabkan kurang baik atau kurang sempurna mengenai tubuh/badan, seperti buta, tuli, bisu, lumpuh, dan lain sebagainya.

Faktor-faktor pada aspek biologis yang diungkap oleh Slameto di atas menurut Djaali (2012), berpengaruh langsung dan tidak langsung terhadap kepribadian seseorang. Dalam hal ini, kondisi tubuh (aspek biologis) menentukan apa yang dapat dilakukan dan apa yang tidak dapat dilakukan seseorang. Secara tidak langsung, seseorang akan merasakan tentang tubuhnya yang juga dipengaruhi oleh perasaan orang lain terhadap tubuhnya. Dalam hubungan ini, guru sebaiknya tidak menyebut ciri-ciri fisik mencolok yang berkonotasi kepada konsep diri yang bersifat negatif bagi si anak. Anak didik yang berkulit hitam misalnya, oleh guru dipanggil dengan "si hitam" terus menerus, sehingga panggilan itu melekat dan menjadi bagian darinya. Maka si anak terus menerus akan merasa tidak nyaman dan mungkin stres karenanya.

Lebih lanjut lagi, termasuk dalam kategori aspek biologis ini adalah konstitusi tubuh/bentuk tubuh yang tercakup di dalamnya aspek motorik seperti sikap badan, cara berjalan, raut muka, gerakan bicara, dan lain sebagainya. Kretschemer dalam bukunya Korperbau und Character, sebagaimana diungkapkan Purwanto (2011) 
dan Baharuddin (2010), menyatakan bahwa antara bentuk tubuh dan watak seseorang terdapat korelasi tertentu. Sehingga ia berpendapat bahwa watak seseorang antara lain ditentukan pula oleh bentuk tubuhnya.

Aspek biologis ini tidak dapat dikatakan sebagai sesuatu yang tidak penting, karena pengelolaan pengajaran maupun pengelolaan sekolah seharusnya menyesuaikan kepada aspek ini. Kalau tidak, tentunya suasana belajar mengajar tidak akan kondusif.

\section{Perbedaan Psikologis}

Para ahli psikologi modern menegaskan bahwa manusia itu merupakan suatu kesatuan jiwa raga yang kegiatannya sebagai keseluruhan, sebagai kesatuan. Kegiatan manusia sehari-hari merupakan kegiatan keseluruhan jiwa raganya. Bukan hanya kegiatan alatalat tubuh saja, atau bukan hanya aktivitas dari kemampuan-kemampuan jiwa satu persatu terlepas daripada yang lain (Ahmadi, 2003). Kalau kita lihat di lingkungan kehidupan masyarakat, secara biologis, anak manusia tidak hanya terdiri dari jenis kelamin laki-laki dan perempuan, tetapi juga terdiri dari berbagai kelompok umur, mulai dari anak kecil, anak usia sekolah, anak remaja, pemuda, dan orang dewasa, termasuk para orang tua lanjut usia. Secara psikologis, mereka itu mempunyai perbedaan dengan karakteristik mereka masing-masing. Ada yang mudah tersenyum, ada yang pemarah, ada yang berjiwa sosial, ada yang egois, ada yang pemalas, ada yang bodoh, ada yang pintar, dan seterusnya yang menurut Djamarah semuanya itu dipengaruhi oleh pembawaan dan lingkungan.

Dalam kaitannya dengan hal tersebut, menurut Khadijah (2006), perbedaan psikologis pada siswa mencakup perbedaan dalam minat, motivasi, dan kepribadian. Ketiga faktor psikologis ini berkorelasi positif dengan hasil belajar yang dicapai. Dalam kondisi minat yang besar terhadap pelajaran, motivasi yang tinggi untuk belajar, dan kemampuan memori yang maksimal, maka hasil belajar yang dicapai juga akan maksimal.

Dalam hubungannya dengan perbedaan psikologis ini, Arden N. Frandsen dalam Suryabrata (2012), menyatakan, bahwa hal-hal yang mendorong seseorang utuk belajar adalah sebagai berikut:

1. Adanya sifat ingin tahu dan ingin menyelidiki dunia yang lebih luas.

2. Adanya sifat yang kreatif yang ada pada manusia dan keinginan untuk selalu maju.

3. Adanya keinginan untuk mendapatkan simpati dari orang tua, guru, dan teman-teman.

4. Adanya keinginan untuk memperbaiki kegagalan yang lalu dengan usaha yang baru, baik dengan koperasi maupun dengan kompetisi.

5. Adanya keinginan untuk mendapatkan rasa aman bila menguasai pelajaran.
6. Adanya ganjaran atau hukuman sebagai akhir daripada belajar.

Menurut Suryabrata (2012), kebutuhan-kebutuhan di atas, tidaklah lepas satu sama lain, melainkan sebagai suatu keseluruhan (sesuatu yang bersifat kompleks) mendorong belajarnya anak. Kompleksnya kebutuhankebutuhan itu sifatnya individual, berbeda antara anak yang satu dengan anak yang lainnya. Pendidik sedapat mungkin harus berusaha untuk mengenal kebutuhan yang mana yang terutama dominan pada anak didiknya.

Secara praktis, penerapan aspek psikologis ini dapat dimanfaatkan oleh guru pada pengelolaan kelas. Misalnya penempatan tempat duduk, seharusnya dipisahkan bagi dua orang yang gemar berbicara untuk meminimalisir kegaduhan yang ditimbulkannya. Anak yang kurang cerdas ditempatkan satu bangku atau satu kelompok dengan anak yang dapat membantunya untuk cepat mengasai materi pelajaran. Anak yang mengalami masalah dalam interaksi sosial (minder), sebaiknya ditempatkan dengan anak yang dapat memotivasi dan membantunya dalam menghadapi permasalahan yang dihadapinya tersebut, begitu seterusnya.

\section{Perbedaan Intelegensi}

Secara umum, menurut Purwanto (1990), intelegensi adalah kemampuan yang dibawa sejak lahir, yang memungkinkan seseorang berbuat sesuatu dengan cara tertentu. Adapun Kartono (1996) mempersamakan intelegensi dengan intelek atau akal budi. Menurutnya, intelegensi adalah kemampuan untuk meletakkan hubungan-hubungan dari proses berfikir. Sementara dengan mengkombinasikan definisi umum yang diungkapkan oleh beberapa pakar, Santrock (2011) mendefinisikan inteligensi sebagai keahlian memecahkan masalah dan kemampuan untuk beradaptasi dan belajar dari pengalaman hidup seharihari.

Bagaimana pun inteligensi didefinisikan atau diterima, para psikolog memandang intelegensi terikat dengan budaya (culture-bound). Karena apa yang dianggap sebagai tingkah laku yang "intelligent" dan apa yang dianggap berguna bagi individu dalam kerangka pertahanan diri berbeda-beda sesuai dengan budayanya. Penduduk South Sea Islander secara "intelligent" memahami gelombang-gelombang laut. Orang Eskimo secara "intelligent" dituntut bisa mempersepsikan berbagai jenis salju, yang perbedaannya tidak dapat dipersepsi oleh kita (Lynn Wilcox, 2012).

Dalam rangka untuk mengetahui tinggi rendahnya intelegensi seseorang, dikembangkan instrumen yang dikenal dengan istilah "Tes Intelegensi." Adapun gambaran mengenai hasi pengetesan kemudian dikenal dengan istilah "Inteligence Quotient, disingkat IQ." Walaupun IQ ini merupakan suatu ukuran, tetapi ia tidak dapat dikatakan sebagai sesuatu yang pasti seperti ukuran dalam meter, kilogram, dan ukuran-ukuran 
matrik lainnya. Ia hanya merupakan perbandingan yang relatif, bukan mutlak kebenarannya (Djamarah, 2010).

Lebih lanjut Djamarah (2010) menyatakan, sampai sekarang orang masih mendebatkan tes yang digunakan untuk mengukur IQ, meskipun sudah diupayakan modifikasi secara terus menerus, namun tes yang dimaksud untuk mengukur kemampuan dasar ini masih juga berisi hal-hal yang mengukur pencapaian dan dipengaruhi oleh lingkungan. Sebagai perumpamaan adalah bentuk soal untuk anak usia tujuh tahun berbunyi: "satu lusin itu isinya berapa?" Untuk anak yang hidup di lingkungan pedagang barangkali istilah "lusin" tidak dirasakan sebagai sesuatunyang asing baginya. Tapi bagi anak lain yang tidak pernah mendengar pembicaraan yang berhubungan dengan istilah itu, tentu tidak akan dapat menjawabnya.

Berdasarkan uraian tersebut dapat disimpulkan bahwa setiap individu memiliki tingkat intelegensi yang berbeda. Adapun untuk mengetahui ukuran yang tepat mengenai perbedaan masing-masing IQ dirasakan terdapat beberapa kesulitan, karena tes intelegensi untuk mengukur IQ tersebut sangat dipengaruhi oleh banyak faktor ketika tes tersebut dilangsungkan, hal ini bisa terdapat kelemahan pada item soal yang diujikan atau pun juga terdapat masalah pada diri anak yang diuji itu sendiri, seperti misalnya kondisi fisik yang kurang sehat, atau kondisi jiwa yang tidak stabil sehingga berdampak terhadap meningkatnya emosi, dan seterusnya.

\section{Perbedaan Individual Lainnya}

Perbedaan individu lain yang banyak diteliti oleh para ahli adalah perbedaan jenis kelamin (gender), perbedaan etnis, dan perbedaan kondisi sosial ekonomi. Mengenai perbedaan jenis kelamin, menurut Byrnes dalam Khodijah, penelitian menunjukkan bahwa kinerja wanita lebih baik daripada laki-laki dalam tes kemampuan membaca pemahaman dan menulis ketika mereka masuk ke kelas satu sekolah dasar. Sedangkan kinerja laki-laki ditemukan lebih baik pada tes matematika, sains, dan ilmu-ilmu sosial pada awal masa remaja. Adapun perbedaan terbesar antara laki-laki dan wanita adalah pada kelancaran dan kualitas menulis pada semua level usia, wanita lebih tinggi dan pada pemecahan masalah matematik selama masa remaja, laki-laki lebih baik (Khadijah, 2006).

Lebih lanjut lagi Khadijah (2006) menjelaskan bahwa perbedaan gender dalam kinerja kognitif, yaitu: (1) pandangan genetik/fisiologis yang menyatakan bahwa gen laki-laki menentukan morfologi otak yang berbeda dengan gen perempuan, (2) pandangan sosialisasi yang menyatakan bahwa perbedaan gender adalah dikarenakan nilai-nilai yang melekat dalam masyarakat yang disalurkan pada siswa oleh keluarga, teman sebaya, dan guru, (3) pandangan differential course work/experience yang menyatakan bahwa perbedaan gender disebabkan perbedaan pengalaman, dan perbedaan ini disebabkan perlakuan yang diberikan secara berbeda terhadap anak laki-laki dan perempuan, dan (4) pandangan proses kognitif yang menyatakan bahwa perbedaan tersebut diakibatkan oleh perbedaan pengetahuan dan strategi yang digunakan, menurut pandangan ini laki-laki lebih baik dari perempuan.

Untuk meminimalisir dampak yang ditimbulkan oleh perlakuan marginalisasi terhadap wanita, menurut Khodijah (2006), dapat dilakukan berbagai intervensi. Studi-studi intervensi yang didesain untuk meningkatkan partisipasi wanita dalam bidang matematika terbukti menghasilkan sikap yang lebih positif tentang matematika dan kecenderungan mengambil jurusan matematika. Hasil yang sama juga dicapai dalam bidang sains. Dalam hubungan ini, Eggen dan Kauchak sebagaimana dikutip Khadijah (2006), menawarkan dua cara yang dapat dilakukan oleh guru, yaitu: (1) menumbuhkan kesadaran dalam dirinya untuk tidak membedakan perlakuan, dan (2) memberikan perlakuan nyata yang sama.

Adapun mengenai perbedaan etnis, Khodijah menginformasikan, bahwa penemuan-penemuan tentang perbedaan etnis cukup konsisten dalam semua mata pelajaran. Kinerja siswa kulit putih ditemukan lebih baik dibandingkan siswa-siswa keturunan Afrika (mungkin penelitian ini dilakukan di Amerika dan Eropa pada umumnya yang tingkat rasisnya sangat tinggi). Dalam hal ini, ada tiga penjelasan utama tentang perbedaan etnis pada kinerja kognitif, yaitu: pandangan cognitive deficit, pandangan kontekstual, dan pandangan cultural incongruity. Masing-masing pandangan tersebut memiliki kelemahan. Meski di Indonesia terdiri dari berbagai etnis, namun selama ini belum pernah dilakukan penelitian tentang perbedaan etnis dalam belajar (Khadijah, 2006).

Selain perbedaan gender dan perbedaan etnis, perbedaan individual lain yang dianggap banyak berpengaruh adalah status sosial ekonomi. Menurut Eggen dan Kauchak dalam Khodijah, pengaruh aspek ini pada belajar dimungkinkan karena tiga hal, yaitu: kebutuhan fisik dan pengalaman yang kurang terpenuhi, pola interaksi di rumah yang kurang demokratis, serta nilai-nilai dan sikap terhadap arti penting ilmu dan pendidikan yang kurang tertanam di rumah (Khadijah, 2006).

\section{Cara Guru Menyikapi Perbedaan Siswa di Kelas}

Salah satu dari lima prinsip pengajaran yang secara relatif berlaku umum menurut $\mathrm{R}$. Ibrahim dan Nana Syaodih S (2003) adalah prinsip perbedaan individu. Pada umumnya, pada jam pelajaran yang sama, guru mengajarkan bahan pelajaran yang sama dengan cara yang sama, sehingga perbedaan individu tersebut sama sekali diabaikan. Pengajaran yang bersifat klasikal ini menurutnya dapat disempurnakan dengan cara-cara sebagai berikut:

1. Dalam mengajar, hendaknya guru menggunakan metode atau strategi belajar mengajar yang bervariasi. Sebab dengan variasi tersebut diharapkan 
beberapa perbedaan kemampuan anak dapat terlayani.

2. Hendaknya digunakan alat atau media pengajaran. Penggunaan media atau alat-alat pengajaran dapat membantu siswa-siswa yang mempunyai kelemahan tertentu. Anak yang kemampuan abstraknya kurang, dapat dibantu dengan alat peraga yang konkrit. Sementara anak yang pendengarannya kurang, dapat diabntu dengan penglihatan.

3. Hendaknya guru memberikan bahan pelajaran tambahan kepada anak-anak yang pandai, untuk mengimbangi kepandaiannya. Bahan tambahan tersebut dapat berupa bahan bacaan, soal-soal yang harus dipecahkan dan sebagainya.

4. Hendaknya guru memberikan bantuan atau bimbingan khusus kepada anak-anak yang kurang pandai atau lambat dalam belajar. Bantuan atau bimbingan dapat diberikan pada jam pelajaran ataupun di luar jam pelajaran.

5. Pemberian tugas-tugas hendaknya disesuaikan dengan minat dan kemampuan anak.

Sebagaimana diinformasikan Khadijah (2006), ada tiga strategi (dua strategi menurut Eggen dan Kauchak, satu strategi menurut Gustafson dan Undheim) yang dapat digunakan guru dalam mengakomodasi perbedaan yang dapat diimplementasikan pada pembelajaran, yaitu:

1. Mempelajari pola-pola interaksi siswa. Guru perlu mempelajari budaya siswa. Ketika berinteraksi dengan siswa, guru harus mendengar siswa dari budaya yang berbeda-beda untuk memahami bagaimana mereka berinteraksi dengan teman sebaya dan orang dewasa lainnya.

2. Merencanakan keterlibatan dan keberhasilan siswa. Dalam merencakan keterlibatan dan keberhasilan siswa ini ada dua cara, yaitu: (a) menggunakan representasi isi kualitas tinggi sebagai poin penting didiskusikan, dan (b) menggunakan pertanyaan terbuka untuk memancing keterlibatan siswa.

3. Pengelompokan kemampuan siswa. Dalam strategi pengelompokan kemampuan ini, guru menempatkan atau mengelompokkan siswa sesuai dengan tingkat kemampuan yang relatif sama.

Selain melakukan strategi untuk mengakomodasi perbedaan, menurut Elliot, dkk, sebagaimana dikutip Khadijah (2006), guru juga perlu melakukan adaptasi pembelajaran. Adaptasi ini perlu dilakukan dalam upaya untuk "menyesuaikan percampuran" antara kondisi siswa dengan metode dan bahan pelajaran yang disampaikan. Elliot, dkk mengaitkan pendapatnya tersebut dengan pendapat Benjamin Bloom, yang mengidentifikasi faktor-faktor penting yang mempengaruhi proses belajar mengajar, yaitu: (1) time on task, yang dapat diartikan sebagai satu tahun ajaran, jumlah hari belajar, jumlah jam per hari, atau jumlah menit untuk setiap mata pelajaran. Menurut Bloom, keaktifan siswa selama waktu tersebut menentukan prestasi yang dicapainya. Artinya, semakin banyak ia aktif maka semakin berprestasi, (2) mastery learning, yang dapat dimaknai dengan pembelajaran yang tepat memungkinkan $90 \%$ siswa dapat menguasai pembelajaran yang diberikan, (3) entry behavior, yaitu keterampilan belajar sebelumnya yang diperlukan sebelum mempelajari sesuatu yang baru, dan (4) hasil belajar, yang ditentukan oleh karakteristik siswa dan kualitas pembelajaran.

Menurut Sudjana (2011), dalam praktek pengajaran, prinsip individual dapat digunakan guru dalam beberapa cara, antara lain:

1. Memberikan tugas-tugas individual sehingga siswa belajar secara mandiri sesuai dengan caranya sendiri.

2. Membuat pengelompokan belajar siswa atas dasar kemampuan belajar yang relatif sama.

3. Menerapkan cara belajar tuntas.

4. Mengembangkan proses belajar sendiri, misalnya dengan menggunakan modul.

5. Memberi kesempatan kepada siswa untuk melakukan kebebasan belajar (independent study) sehingga siswa bebas mempelajari bahan sesuai dengan kemauan dan kepentingannya.

Sementara itu, Khadijah

menginformasikan, bahwa teori-teori dan penemuan tentang perbedaan individual memberikan sejumlah anjuran tentang cara mengeliminir perbedaan, yaitu:

1. Program nutrisi dan stimulasi harus diberikan pada anak-anak yang berasal dari keluarga berpenghasilan rendah.

2. Penciptaan mekanisme sosial yang mendukung.

3. Pembelajaran secara kontekstual, disesuaikan dengan perbedaan masing-masing.

4. Mengadakan program remediasi dua tahap.

5. Pengembangan profesionalisme guru dalam upaya meningkatkan pembelajaran yang berorientasi perbedaan.

\section{SIMPULAN}

Karakteristik individual masing-masing terletak pada aspek biologis (fisiologis) yang meliputi bentuk, anatomi, susunan dan struktur tubuh manusia, serta aspek psikologis yang meliputi minat, bakat, intelegensi, emosi, dan lain sebagainya. Kedua aspek ini membentuk suatu perilaku tertentu pada manusia yang menjadikannya berbeda dengan manusia yang lainnya.

Dalam menyikapi perbedaan-perbedaan ini, dalam proses pembelajaran di kelas, guru dapat melakukan halhal sebagai berikut:

1. Dalam mengajar, hendaknya guru menggunakan metode atau strategi belajar mengajar yang bervariasi. Sebab dengan variasi tersebut diharapkan beberapa perbedaan kemampuan anak dapat terlayani.

2. Hendaknya digunakan alat atau media pengajaran. Penggunaan media atau alat-alat pengajaran dapat 
membantu siswa-siswa yang mempunyai kelemahan tertentu. Anak yang kemampuan abstraknya kurang, dapat dibantu dengan alat peraga yang konkrit. Sementara anak yang pendengarannya kurang, dapat diabntu dengan penglihatan.

3. Hendaknya guru memberikan bahan pelajaran tambahan kepada anak-anak yang pandai, untuk mengimbangi kepandaiannya. Bahan tambahan tersebut dapat berupa bahan bacaan, soal-soal yang harus dipecahkan dan sebagainya.

4. Hendaknya guru memberikan bantuan atau bimbingan khusus kepada anak-anak yang kurang pandai atau lambat dalam belajar. Bantuan atau bimbingan dapat diberikan pada jam pelajaran ataupun di luar jam pelajaran.

5. Pemberian tugas-tugas hendaknya disesuaikan dengan minat dan kemampuan anak.

\section{DAFTAR PUSTAKA}

Ahmadi, Abu. (2003). Ilmu Sosial Dasar, cet. 4. Jakarta: Rineka Cipta.

Baharuddin. (2010). Psikologi Pendidikan: Refleksi Teoretis terhadap Fenomena, cet. 3. Yogyakarta: Ar-Ruzz Media.

Djaali. (2012). Psikologi Pendidikan, cet. 6. Jakarta: Bumi Aksara.

Djamarah, Syaiful Bahri. (2002). Psikologi Belajar. Jakarta: Rineka Cipta. --. (2010). Guru dan Anak Didik dalam Interaksi Edukatif: Suatu Pendekatan Teoretis Psikologis, edisi revisi, cet. 3. Jakarta: Rineka Cipta.

--------- dan Aswan Zain. (2010). Strategi Belajar Mengajar, cet. 4. Jakarta: Rineka Cipta.

Hamalik, Oemar. (2009). Psikologi Belajar dan Mengajar, cet. 6. Bandung: Sinar Baru Algensindo.

Ibrahim, R. dan Nana Syaodih S. (2003). Perencanaan Pengajaran, cet. 2. Jakarta: Departemen Pendidikan dan Kebudayaan bekerjasama dengan Rineka Cipta.

Kartono, Kartini. (1996). Psikologi Umum, cet. 3. Bandung: Mandar Maju.

Khadijah, Nyayu. (2006). Psikologi Belajar. Palembang: IAIN Raden Fatah Press.

Purwanto, M. Ngalim. (1990). Psikologi Pendidikan. Bandung: Remaja Rosdakarya. . (2011). Ilmu Pendidikan Teoritis dan Praktis, ed. 2, cet. 20. Bandung: Remaja Rosdakarya.

Santrock, John W. (2011). Psikologi Pendidikan, Edisi Kedua, terjemahan Tri Wibowo B.S. cet. 4. Jakarta: Kencana.

Sardiman A.M. (2012). Interaksi dan Motivasi BelajarMengajar, cet. 21. Jakarta: Rajawali Pers.

Slameto. (2010). Belajar dan Faktor-Faktor yang Mempengaruhinya, edisi revisi, cet. 5. Jakarta: Rineka Cipta.
Sudjana, Nana. (2011). Dasar-dasar Proses Belajar Mengajar, cet. 12. Bandung: Sinar Baru Algensindo.

Suryabrata, Sumadi. (2012). Psikologi Pendidikan, ed. 5, cet. 19. Jakarta: Rajawali Pers.

Sunarto dan Ny. B. Agung Hartono. (2008). Perkembangan Peserta Didik, cet. 4. Jakarta: Rineka Cipta.

Tafsir, Ahmad. (2012). Filsafat Pendidikan Islami Integrasi Jasmani, Rohani, dan Kalbu Memanusiakan Manusia, cet. 5. Bandung: Remaja Rosdakarya.

Tirtarahardja, Umar dan S. L. La Sulo. (2008). Pengantar Pendidikan, edisi revisi, cet. 2. Jakarta: Rineka Cipta.

Wilcox, Lynn. (2012). Criticism of Islam Psychology, diterjemahkan oleh Kumalahadi P. dengan judul Psikologi Kepribadian. Yogyakarta: IRCiSoD. 